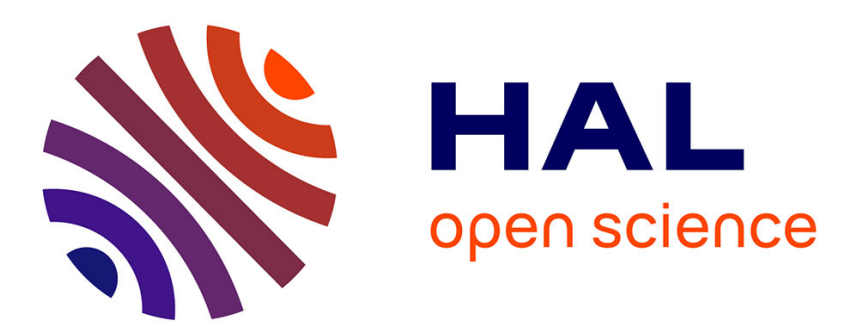

\title{
Vulnerability and costs of adaptation strategies for housing subjected to flood risks: Application to La Guérinière France
}

\author{
Axel Creach, Emilio Bastidas-Arteaga, Sophie Pardo, Denis Mercier
}

\section{To cite this version:}

Axel Creach, Emilio Bastidas-Arteaga, Sophie Pardo, Denis Mercier. Vulnerability and costs of adaptation strategies for housing subjected to flood risks: Application to La Guérinière France. Marine Policy, 2020, 117, pp.103438. 10.1016/j.marpol.2019.02.010 . hal-02114564

\author{
HAL Id: hal-02114564 \\ https://hal.science/hal-02114564
}

Submitted on 29 Apr 2019

HAL is a multi-disciplinary open access archive for the deposit and dissemination of scientific research documents, whether they are published or not. The documents may come from teaching and research institutions in France or abroad, or from public or private research centers.
L'archive ouverte pluridisciplinaire HAL, est destinée au dépôt et à la diffusion de documents scientifiques de niveau recherche, publiés ou non, émanant des établissements d'enseignement et de recherche français ou étrangers, des laboratoires publics ou privés. 


\title{
Vulnerability and costs of adaptation strategies for housing subjected to flood risks: application to La Guérinière France
}

\author{
Axel Creach ${ }^{1,2}$, Emilio Bastidas-Arteaga ${ }^{3}$, Sophie Pardo ${ }^{4}$ and Denis Mercier ${ }^{5}$ \\ 1. Université de Nantes, Centre François Viète d'histoire des sciences et des techniques (EA 1161), UFR des \\ Sciences et des Techniques de Nantes, 2, rue de la Houssinière, BP 92208 - 44322 Nantes, France, Axel.Creach@univ- \\ nantes.fr \\ 2. Laboratoire LETG-Nantes Géolittomer, UMR 6554, CNRS, Axel.Creach@univ-nantes.fr \\ 3. Université de Nantes, Institut de Recherche en Génie Civil et Mécanique (GeM), UMR 6183, CNRS, \\ Emilio.Bastidas@univ-nantes.fr \\ 4. Université de Nantes, Institut d'Economie et de Management de Nantes, Sophie.Pardo@univ-nantes.fr \\ 5. Université Paris-Sorbonne (Paris IV), UFR de Géographie et d'Aménagement, Laboratoire ENeC, UMR 8185, \\ CNRS, denis.mercier@paris-sorbonne.fr
}

\begin{abstract}
Coastal flooding along the Atlantic coast caused by Storm Xynthia killed 41 people. The location and configuration of residential housing were the main factors affecting the vulnerability of people to flooding. The French government responded by destroying buildings in the most flood-prone areas and relocating residents to safer areas. This strategy attracted much criticism, in particular because of the high costs involved with demolition on this scale, and that not insufficient consideration was given to other possible solutions. In this study, the goal is to compare different adaptation strategies in terms of cost of implementation and efficiency in order to reduce the vulnerability of houses to flooding. The strategies are grouped based on: (i) protection, (ii) relocation, (iii) housing architectural adaptation, and (iv) preventive warning and evacuation. This work is applied to La Guérinière, an Atlantic coastal town at risk of coastal flooding, although it was not impacted by Storm Xynthia. The initial results show that the most efficient strategy to reduce housing vulnerability to coastal flooding is also the most expensive. Ranked from the most to the least efficient and expensive, the strategies are as follows: (i) relocation, (ii) housing architectural adaptation, (iii) protection, (iv) and preventive warning and evacuation. Until now, these strategies have been limited as they omit human behaviour in response to coastal flooding scenarios. Therefore, this study examines the role of human behaviour in relation to different mitigative strategies. The efficiency and costs of the strategies are then reappraised.
\end{abstract}

Keywords: Xynthia, coastal flood, human vulnerability, residential houses, climate change, adaptation strategies, economic assessment.

\section{$1 \quad$ Introduction}

Storm Xynthia hit the French Atlantic coast from the Loire in the north to the Gironde estuaries in the south in February 2010. The combination of strong winds and a high tide coefficient (102) 
produced an exceptionally high storm surge along the coasts of Vendée and Charente-Maritime that resulted in 50,000 hectares in low-lying areas being submerged [1,2]. Despite the area having been classified as being at risk of coastal flooding, French stakeholders regarded the risk as being sufficiently low to warrant continued urban development [3,4] However, Storm Xynthia in 2010 led to 41 fatalities caused by drowning [3,4]. Notably, $93 \%$ of deaths occurred in residential buildings.

Subsequent investigations into the factors contributing to the 41 fatalities highlighted the importance of both the location and configuration of residential buildings [3,4]. Statistics show that: (i) $100 \%$ of deaths occurred in buildings subjected to water levels exceeding $1 \mathrm{~m}$; (ii) $90 \%$ of deaths occurred in buildings located at less than 400 meters from the flood defences; and (iii) $78 \%$ of deaths were reported in single-storey buildings. Thus the location and configuration of residential buildings emerged as the most important variables contributing to human vulnerability to coastal flood events [5].

Following Storm Xynthia, the French government decided to implement a "black area policy" which involved demolishing houses located in areas of high flood risk areas. This measure was criticized for its hasty implementation, the criteria used to delineate the black areas [6], and its high cost [7]. The "black areas policy" involves expensive 'relocation' in the short-term but is nonetheless effective in protecting human life against coastal flood risks. Nevertheless, several questions concerning the potential implementation and effectiveness of alternative measures remain. For instance, the elevation of flood defences could be increased to protect the more exposed areas instead of demolishing houses and relocating people. In addition, single-storey houses could be equipped with a "shelter floor."

Against this backdrop, the main objective of this study is to evaluate the vulnerability and costs of different adaptation measures to protect occupied houses located in high flood risk areas on the French Atlantic coast.

\section{Material and methods}

This section starts by describing and justifying the selection of the study site (Section 2.1). Section 2.2 describes and illustrates the methodology proposed to perform the vulnerability diagnosis of this site. Section 2.3 details the adaptation strategies that could be implemented to face flooding risks. Section 2.4 describes the discount rates used for cost analysis. Finally, section 2.5 presents the considered climate change scenarios.

\subsection{Study site: La Guérinière town on the Noirmoutier Island}

\subsubsection{Noirmoutier Island: a low-lying area}

Noirmoutier Island is a French Atlantic island $\left(\right.$ area of $\left.49 \mathrm{~km}^{2}\right)$, located in the Vendée department (Figure 1). It is a low-lying area. Around 68\% of the island would have been under water during storm Xynthia if it had not been protected [8]. The island is currently protected from the sea by a 24-km stretch of flood defences on the east coast and by a sand barrier on the west coast [9]. 


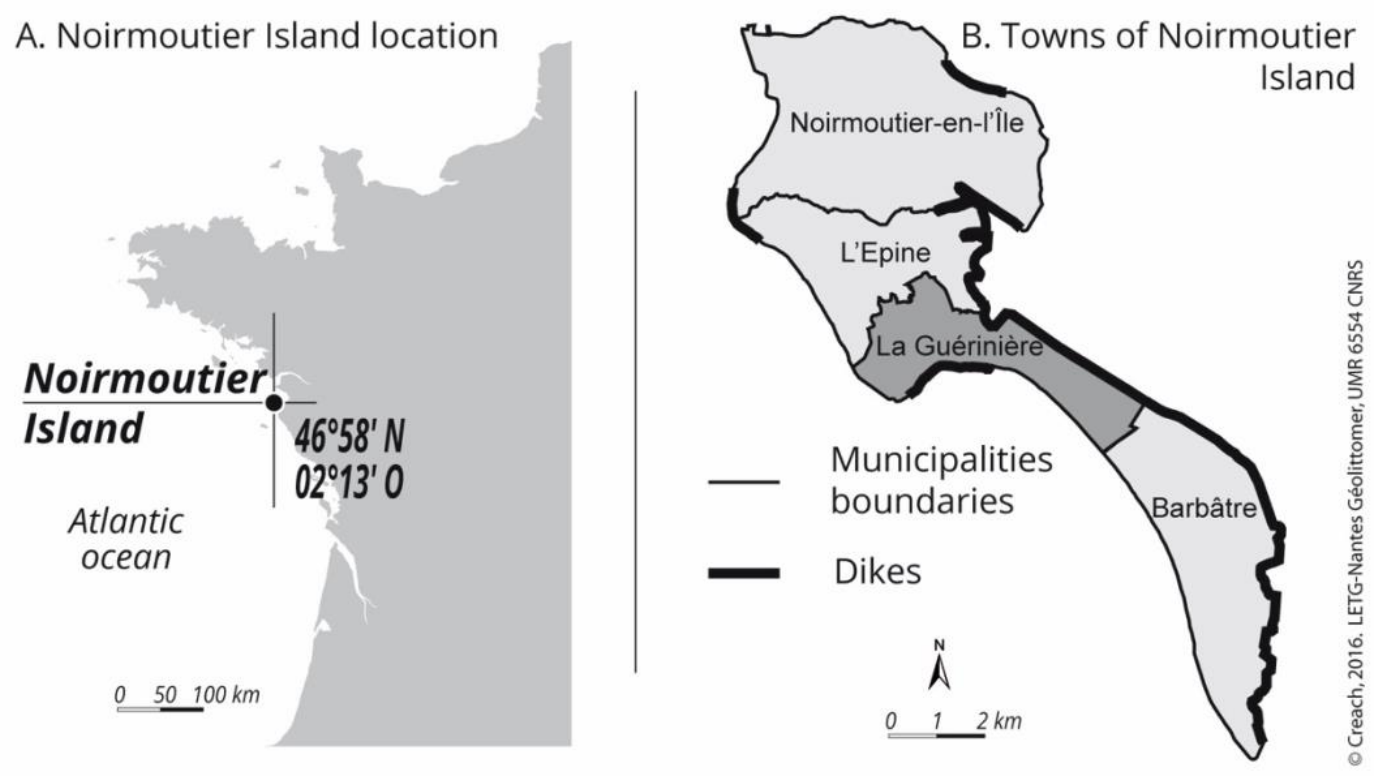

Figure 1: Location of La Guérinière town

Since 1968, the population of the island has increased by $19 \%$. Meanwhile, the urbanization increased by $+162 \%$ during the same period [10]. This important growth is mainly due to the construction of leisure residential houses which represented 50\% of the urbanized area in 2011 [11]. However, the new leisure housing is mainly located in low-lying areas [8] and today one-half of the constructions is located in potential flooding areas.

Noirmoutier island was not severely affected by Storm Xynthia in 2010, with only 3\% of the territory flooded [12]. Since the 1950s, no major flooding events have occurred, but $2 / 3$ of the island were flooded in 1937; however, the relatively unpopulated nature of the island at that time resulted in minimal impacts on human life and infrastructure [13]. Taking into account the natural risk of flooding of this island, the additional risk related to sea-level rise and the present urbanization of the island, it is important to evaluate the potential consequences of an extreme event occurring today. This study focuses on one the most vulnerable towns of the island called La Guérinière.

\subsubsection{La Guérinière: the most exposed town}

La Guérinière covers $7.8 \mathrm{~km}^{2}$ (16\% of the island) with $80 \%$ of its territory located below the seawater level attained during Storm Xynthia (4.20 m NGF) [12]. The town is in the narrowest part of the island (less than $800 \mathrm{~m}$ between the west coast and the east coast) which increases the risk of coastal flooding. On the east coast, La Guérinière is protected from the Bay of Bourgneuf by flood defences which are $5 \mathrm{~m}$ high (following renovation in 2014) (Figure 1). On the west coast, the town is isolated from the Atlantic Ocean by a sand barrier which is high and wide on the north and the south, but narrow and less elevated in the central part of the town (approximately $5 \mathrm{~m}$ high and $50 \mathrm{~m}$ wide) and supported by a sea-wall.

The town had 2,667 houses with 1,460 inhabitants in 2011 [11]. The number of houses has increased by 144\% since 1968 and presently $73 \%$ are located under the sea-water level reached during Storm Xynthia [10]. Considering the fact that the town is in the narrowest part of the island and there is a large concentration of houses located in low-lying areas, La Guérinière is the most exposed town of Noirmoutier Island to coastal flooding. 


\subsection{Description of the Extreme Inherent Vulnerability (VIE) index}

The VIE index is a method developed by Creach (2015) [5] to assess the vulnerability of residential buildings subjected to coastal flood risks. It is a micro-scale index that aims to identify houses in which people can be trapped inside during coastal flooding events as a function of building location and architecture.

\subsubsection{Background}

The method was developed in light of the number of deaths (100\%) having occurred inside houses during Storm Xynthia Jonkman, and Kelman [14] found that $6 \%$ of deaths were located inside houses for 13 flood events of relatively low magnitude compared to those generated by Storm Xynthia [15]. Jonkman et al. [16] subsequently determined that 54\% of fatalities had occurred inside houses during Storm Katrina. These data have prompted growing interest in the number of fatalities likely to occur during extreme events in the future.

For Storm Xynthia, the location and configuration of houses were the most important factors accounting for the number of deaths. According to Vinet [3], the 41 deaths resulting from Storm Xynthia occurred in buildings subjected to water levels in excess of $1 \mathrm{~m}$. Furthermore, $90 \%$ of deaths occurred in houses within $400 \mathrm{~m}$ of flood defences, while $78 \%$ occurred in single-storey buildings. These results show that location (low-lying area, proximity of flood defences) and configuration (architecture) of residential buildings place people at greatest risk during major flood events.

\subsubsection{Description of the method}

The VIE index is based on four criteria used to identify the buildings in which death may occur during a coastal flood event. These criteria are outlined below (and see Figure 2):

- $\quad$ The potential water level inside the building in case of flood $(\mathrm{Cr} 1)$;

- The distance between buildings and flood defences (e.g. dikes) $(\mathrm{Cr} 2)$;

- $\quad$ The architectural type of building (Cr3): (e.g. single or multi-storey);

- The proximity of buildings to natural rescue points $(\mathrm{Cr} 4)$ (e.g. areas of higher relief, margins of flood prone areas).

For each criterion, a mark between 4 (high vulnerability) and 0 (no vulnerability) is given for each building. To confirm the robustness of the VIE index, a correlation analysis was performed to check the independence between the criteria (non-redundancy) and the correlation of criteria with the results as this is recommended to generate good composite indicators [17]. A Monte-Carlo test was then performed to confirm the robustness of the index [5] on the basis of the formula in Figure 2 [5], This formula gives a score between 0 and 12 which represents the level of vulnerability of houses for people.

To map the results from the VIE index, four classes were identified (Figure 2):

- $\quad$ Green class (VIE equal to zero) includes buildings where no vulnerability is identified (they are not exposed to coastal flooding). It is important to note that if the result of the first criterion (potential water level inside) is 0 (no water inside), the result of the VIE index is null.

- Yellow class (VIE index from 1-5) concerns buildings that are exposed to flooding but their location or characteristics do not result in high risk for people.

- $\quad$ Red class (VIE index from 5-8) encompasses buildings in which risk particularly vulnerable people (young, elder, disabled) are at risk of drowning.

- Black class (VIE index from 8-12) concerns buildings in which death is highly likely to occur in case of flooding due to the location and configuration of the building.

For purposes of validation, the VIE index was applied to three towns impacted by Storm Xynthia and compared to the death toll for this event [5]. It was found that $83 \%$ of deaths were in buildings identified in the black class by the VIE Index and $17 \%$ in the red class. 


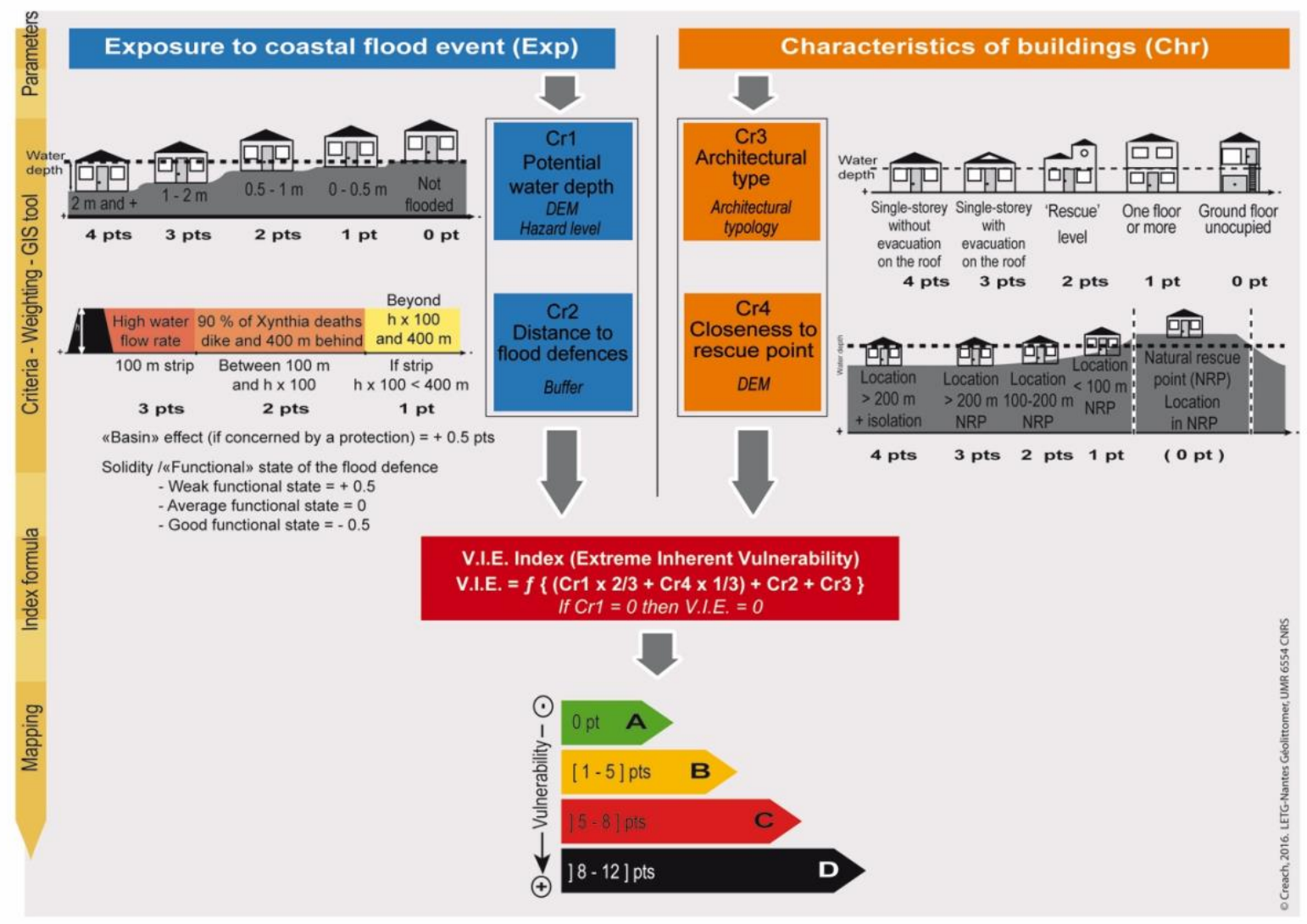

Figure 2: Summary of the VIE Index method

For this study, the VIE index is used to assess the vulnerability of people in houses subjected to different flood scenarios (defined in Section 2.5). The VIE index is then applied to estimate the efficiency of four adaptation strategies (Section 2.3) to reduce the vulnerability of people residing in houses to death by flooding.

\subsection{Adaptation strategies}

Various adaptation strategies can be implemented to reduce the vulnerability of houses for people and to protect human life from coastal flood risk. Table 1 summarizes the classification of structural adaptation strategies found in the literature which could be applied to buildings [18-20]. Moreover, prevention and warning are also crucial to prevent fatalities [21-24]. In this way, this study considers protection, retreat and two accommodation strategies. The first accommodation strategy encompasses housing architectural adaptation that aims to protect the population, and the second includes those actions that facilitate preventive warning and evacuation in case of an imminent flooding event. 
Table 1: Adaptation strategies for housing subjected to coastal flooding risks (adapted from [20])

Adaptation strategy
Protection: construction of a protective structure that
Retreat: moving an exposed building to safe zones
[25]. This strategy was adopted after Storm Xynthia via the
"black areas policy."
Accommodation: minimization of flood impact by
renovating housing at the original location.

\subsubsection{Protection: dike reinforcement and rising}

\subsubsection{Objectives and implementation}

This strategy artificially aims at maintaining the position of the shoreline permanently (construction of a dike or a protective wall), or sand dunes to reduce the likelihood of floods [18-20]. Nevertheless, protection structures can fail for three key reasons: (i) structural failure, (ii) over-topping, and (iii) improper maintenance or degradation during their life-time. Despite criticisms regarding the exponential costs of adapting flood defences [26] and the false sense of security that they provide to people living behind these structures [27], this strategy is popular in developed countries [19].

This study considers only the adaptation of existing protection facilities to overcome sea-level rise due to climate change. In France, since 2015 and the introduction of the GEMAPI law (GEstion des Milieux Aquatiques et Prévention des Inondations, i.e. Water Environment and Floods Prevention Management), local authorities are now responsible for management of flood defences. This signifies a considerable change because prior to $2010,3000 \mathrm{~km}$ of pre-existing flood defences were not managed or maintained properly. [22].

\subsubsection{Costs}

Dollet and Sylla [28] quantified the reinforcement and rising costs for a segment of a dike located in Noirmoutier island, France. A dike rise of $120 \mathrm{~cm}$ was considered sufficient to raise the dike crest to an altitude higher than the present sea level $(4.20 \mathrm{~m} \mathrm{NGF})$, but also with extra protection $(60 \mathrm{~cm})$ to mitigate against future sea level rise. The new altitude is $5 \mathrm{~m} \mathrm{NGF}$ as recommended by Noirmoutier's Council. The total cost of this work was estimated at $€ 500$ per $\mathrm{m}$, plus an annual maintenance allowance equivalent to $2 \%$ of the investment ( $€ 10$ per $\mathrm{m}$, annually). Although this price range is similar to those outlined in other studies [29], it is important to note that these costs vary depending on the initial state of the structure, required elevation increase, and/or availability and proximity of necessary construction materials.

\subsubsection{Impact on VIE Index calculation}

This strategy affects the second criterion of the index which concerns the distance between flood defences and buildings. This study considers that flood defences are reinforced and therefore the probability of collapse is less important in reducing the risk of flooding ( 0.5 is retrenched to the mark considering that the defence is in a good functional state). In contrast, raising the elevation of flood defences could increase the surprise effect in case of failure and therefore increase flood vulnerability of houses and their occupants. 


\subsubsection{Retreat: relocation}

\subsubsection{Objectives and implementation}

In some cases, implementation of protective strategies for high-risk exposure levels becomes very expensive and accommodation strategies cannot guarantee a significant decrease in the vulnerability of houses and their occupants. Consequently, it is necessary to relocate vulnerable buildings outside hazard areas.

This measure has been previously implemented for housing and facilities placed in zones where coastal erosion is unavoidable [19]. Regarding the marine flooding risk, this approach is still new in France - i.e., the "black areas policy" was the first example of the application of this strategy following the Xynthia event. The application of the policy led to the demolition of 1628 houses supposedly within a high flood-risk zone, resulting in a total cost of $€ 315.7$ million. In the context of sea level rise due to climate change, this strategy should become widely employed in the future, as proposed in the French national strategy for shoreline management [25].

The implementation of this type of strategy requires the purchase and destruction of more exposed buildings and facilities. Although retreat is expensive in the short-term, it should eliminate future flooding consequences. Like protection, this strategy also concerns mainly public authorities and is carried out by friendly takeovers or expropriations.

\subsubsection{Costs}

Housing relocation costs after the Xynthia event are not considered in this study. Therefore, the costs for this adaptation strategy are estimated based on available information as the sum of purchase and demolition costs. Purchase costs in coastal zones are influenced by larger land pressure that differs for each construction located in a given location. To account for these variations, this study estimates a mean cost per $\mathrm{m}^{2}$ for La Guérinière from information available from three specialized websites (http://www.meilleursagents.com/prix-immobilier, $\quad$ http://prix-immobilier.drimki.fr $\quad$ and htpp://Efficity.com). Data for seven towns located around La Guérinière zone indicate a mean purchase cost of $€ 2,366 / \mathrm{m}^{2}$ with a standard deviation of $€ 555 / \mathrm{m}^{2}$. This cost can then be multiplied by the surface area of the buildings shortlisted for demolition to estimate the overall purchase cost.

Demolition costs are estimated at $€ 20,000$ per building, corresponding to the mean cost estimated from the website: http://www.renovationettravaux.fr/cout-demolition-maison-prix-devis. Retreat costs could be completed by considering additional costs such as those related to land restoration or the building costs associated with new "retreat" areas.

\subsubsection{Impact on VIE Index calculation}

This strategy has no direct impact on any of the VIE index criteria. In this study, buildings identified in the black class without considering adaptation measures are considered too dangerous and consequently it is supposed that they need to be demolished.

\subsubsection{Accommodation 1: housing architectural adaptation}

\subsubsection{Objectives and implementation}

This strategy focuses on adapting the buildings to reduce occupants' vulnerability to coastal flood events. The different types of solutions can be classified into two categories:

- $\quad$ measures that reduce or avoid potential flooding zones: increase the level of the first floor by using of stilts, construction mounds around the building, use a floating foundation, etc.

- $\quad$ measures that provide a safe zone in case of a flooding event: addition of a refuge floor, conversion of loft, etc. 
The implementation of these solutions depends on both the use and temporality of construction. For example, the first category would be more suitable for new buildings while the second could be more appropriate for existing or secondary constructions. The present study only considers architectural adaptation of existing buildings. It will then focus specifically on the construction of a refuge floor, as proposed by the French repository for flood prevention works in existing houses [30] (Figure 3).

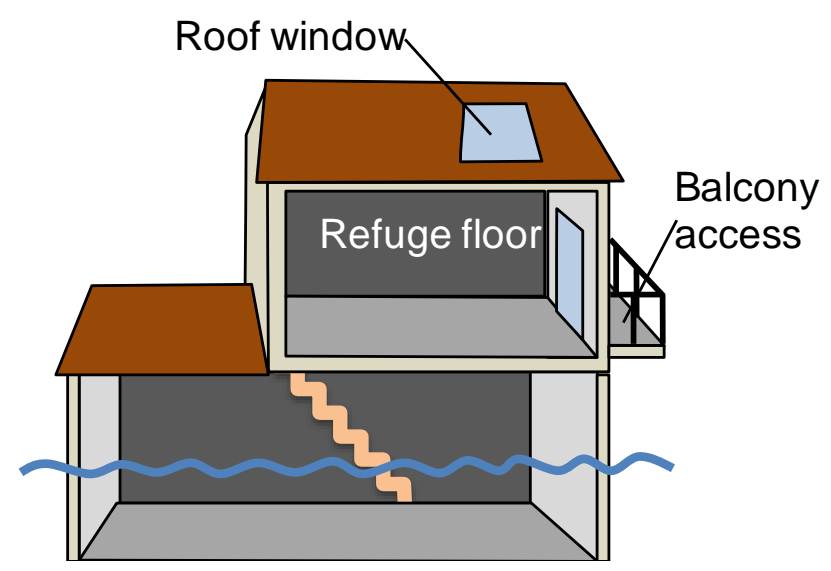

Figure 3: Example of creation of a refuge floor (according to [30])

Considering that $17 \%$ of deaths occurred in single-storey buildings during the Xynthia event (Vinet et al., 2011; [31]), the implementation of this adaptation strategy could be cost-effective. However, it should be noted that it does not guarantee fully effective security for occupants in case of a coastal flooding event. In some cases they could be trapped on the ground floor despite the presence of a refuge. The application of the strategy concerns mainly private individual initiatives but it may also be supported by public financial incentives.

\subsubsection{Costs}

The solution takes into account the recommendation of the French ministry for flood prevention works in relation to existing housing [30]. It consists of constructing a refuge floor with the following characteristics: (i) surface area varying from $9-20 \mathrm{~m}^{2}$, (ii) a floor level higher than $4.2 \mathrm{~m}$ above the sealevel, and (iii) external access (roof window or balcony) allowing evacuation by helicopter or boat. On the basis of these requirements, Festuot and Guillaume [32] estimated that the minimum construction cost of a refuge floor of $20 \mathrm{~m}^{2}$ is $€ 19,000$. However, this cost may vary depending on the type of existing foundation and structure as well as the selection of construction materials. Potential benefits include the use of the new space as an active part of the house and to increase the economic value of the building.

\subsubsection{Impact on VIE Index calculation}

The measure of housing architectural adaptation has impacts the third criteria of the index: the architectural configuration of the house. Single-storey buildings identified in red and black classes in the initial results could be adapted by building a rescue level.

\subsubsection{Accommodation 2: preventive warning and evacuation}

\subsubsection{Objectives and implementation}

This strategy aims to facilitate preventive evacuation in case of an alert of a coastal flooding event. Kolen et al. [23] affirmed that such an evacuation would significantly reduce human fatalities during Storm Xynthia. Moreover, Chadenas et al. [33] showed that prevention could be greatly improved for coastal floods in France. However, at the time of Storm Xynthia, no real-time monitoring 
of coastal surges and warning was available along the French Coast [22]. In 2017, the only existing system was capable of providing information at the department scale.

Nevertheless, the effectiveness of an evacuation depends on: (i) the number of people who effectively evacuate, which can be extremely variable [21]; and (ii) the time available between the beginning of the alert and the occurrence of the storm event as well as evacuation logistics [34].

A successful warning and evacuation, in case of a coastal flooding event, requires that people have awareness of flooding-risk and that previous preparation has been undertaken. This necessitates that appropriate guidelines are issued regarding evacuation procedures and drills conducted every so often. The difficulty with such a measure is maintaining risk awareness as an ongoing process.

This strategy can be executed at two levels:

- Implementation of preventive measures for population information and education: this task could be carried out by disseminating regulatory documents for information and prevention (risk prevention plan, communal information document on major risks, communal safeguard plan, etc.) and conducting evacuation drills regularly. These actions would facilitate the successful evacuation of inhabitants in case of an alert.

- Development of evacuation equipment or refuge structures: since the total evacuation of an area is unrealistic, provision of compulsory household equipment such as the 'standby emergency kit' (http: //www.developpement-durable.gouv.fr/Kit-d-attente-des-secourspendant.html) could be made available following the recommendation of the Ministry of Ecology. Specific structures like shelter platforms could also be installed for use as a refuge. Various types of refuge platforms have been already implemented elsewhere [10].

The application of this strategy depends primarily on public authorities. Nevertheless, several private facilities such as holiday centres have already built refuge platforms [10].

\subsubsection{Costs}

This study considers the implementation of information and educational measures as well as the construction of a refuge shelter platform. Preventive actions are defined at the municipal level. The costs of the production and dissemination of the various documents and evacuation training for the Flood Prevention Action Plan (PAPI in French) for La Rochelle (France) are $€ 357,000$ [35]. An update every five years is envisaged to maintain and adapt risk awareness.

The installation of shelter platforms is compulsory in certain holiday centres and campgrounds. According to one company that constructed and installed them (TDEM company), the cost of a platform with a capacity of 150-200 people is about $€ 80,000$. This cost varies depending on the size and structure of equipment (staircases, lifts, etc.). Finally, the cost of household equipment 'standby emergency kit' is estimated at $€ 250$ (personal estimation on the basis of the list given by Ministry of Ecology).

\subsubsection{Impact on VIE Index calculation}

This adaptation measure impacts on the proximity of buildings to a rescue point criterion of the VIE index. We consider one adaptation scenario where each house is located within $200 \mathrm{~m}$ of a natural or artificial shelter or safe haven.

\subsection{Discount rates}

There is some uncertainty about the level of discount rate, particularly for climate change economic assessments (e.g. [36]. France used a discount rate of $8 \%$ to evaluate public investments from 1985 to 2005. However, following the 2005 Lebègue report [37], the 'Commissariat Général au Plan' has recommended a $4 \%$ discount rate for short term investments and a lower discount rate of $2 \%$ for cash flows occurring after more than 30 years [38]. These discount rates were revised in 2013 by the 'Commissariat Général à la Strategie et à la Prospective' recommending 2.5\% and 1.5\% discount rates for short term (lifetime less than 70 years) and long term investments, respectively [39]. Quinet et al. 
[39] also recommends carrying out a sensitivity analysis with a $4.5 \%$ discount rate to compare new and old approaches. Other countries and institutions use different discount rates. The European Commission recommends a 5\% discount rate [40]; Infrastructure Australia recommends discount rates of 4\%, 7\% and $10 \%$ for infrastructure projects [41]; and other discount rates vary from 3\% (Germany) to over 10\% (World Bank) [40].

Discount rates are generally assumed to be constant with time. However, this may not be appropriate when considering intergenerational effects often associated with climate change policy decisions (e.g. [42]. Projects with significant effects beyond 30-50 years are considered intergenerational, and so for example, the British Treasury recommends the following time-decreasing discount rates [43]: 3.5\% (0-30 years), 3.0\% (31-75 years), 2.5\% (76-125 years), 2.0\% (126-200 years), $1.5 \%$ (201-300 years), and $1.0 \%$ (300+ years). However, there is some controversy about timedecreasing discount rates (e.g. [44], and the Australian Office of Best Practice and Regulation (OBPR) states that 'there is no consensus about how to value impacts on future generations' and 'Rather than use an arbitrarily lower discount rate, the OBPR suggests that the effects on future generations be considered explicitly' [45]. Nonetheless, the 2006 U.K. Stern Review adopted a discount rate of 1.4\% [46], and the Australian Garnaut Review adopted discount rates of $1.35 \%$ and 2.65\% [47]. These relatively low discount rates were selected so as not to underestimate climate impacts on future generations. However, others suggest higher discount rates when assessing economic impacts of climate change (e.g, [48]).

The above quantification of discount rates relates mainly to public-sector investments in infrastructure. Private investments in infrastructure, such as the owners of a port, power station or airport (etc), tend to include a risk premium which leads to a higher discount rate [49]. The marginal rate of return of private investments is suggested as one method to derive discount rates for private investments (e.g. [42]). According to [42], the best 'proxy' for the marginal rate of return of private investments is the before-tax rate of return on corporate bonds - or approximately $4.5 \%$.

The present study considers the discount rate recommended by the 'Commissariat Général à la Strategie et à la Prospective' in 2005 in the Lebègue report [37].

\subsection{Climate change scenarios}

This study analyses the vulnerability of houses for people and costs of adaptation strategies for four scenarios of coastal flooding: frequent, medium, medium including sea level rise in 2100 and extreme. These scenarios have been defined on the basis of studies made by the French administration to implement the Flood Directive [50]. We use the values proposed in a study carried out in Fromentine which is close to La Guérinière [51]. Table 2 describes the characteristics of each scenario.

Table 2: Description of the considered coastal flood scenarios (based on [51])

\begin{tabular}{lll}
\hline Scenario & Return period & $\begin{array}{l}\text { Sea water level at Fromentine (in front of } \\
\text { Noirmoutier Island) }\end{array}$ \\
\hline Frequent & 10 years & $3.6 \mathrm{~m} \mathrm{NGF}$ \\
Medium & $100-300$ years & $4.2 \mathrm{~m} \mathrm{NGF}$ \\
Medium $+\mathrm{SLR}^{*}$ & Same as above $+0.6 \mathrm{~m}$ & $4.8 \mathrm{~m} \mathrm{NGF}$ \\
Extreme & 1000 years or more & $5.2 \mathrm{~m} \mathrm{NGF}$ \\
\hline
\end{tabular}

${ }^{*}$ SLR means Sea Level Rise 
Based on the sea levels presented in Table 2, the potentially flooded areas were determined using a "static" flood model [52] that uses high resolution topographic datasets (Lidar Litto-3D) [53] and considers that inland areas located below sea level are inundated within $100 \mathrm{~m}$ of the seashore. The difference between sea level and the ground level of the house permits the potential water level in case of flooding to be estimated. This method is relatively simple but has some limitations that are discussed in Section 4.

\section{Results}

\subsection{VIE Index for existing housing configuration}

For each flood scenario, we calculated the results of the VIE index for every house ( 2817 houses identified in total) of La Guérinière. Table 3 summarizes the results for the flood scenarios. As expected, vulnerability of houses for people increases with the intensity of the coastal flood event. For frequent, low magnitude events, half of the buildings (47\%) are located outside the flooded zone whereas only $26 \%$ are outside during high magnitude, low frequency events. This means that $74 \%$ of the houses in La Guérinière could be flooded during an extreme flood. Houses within the red and black classes are the most vulnerable. In particular, for the black class, the number of houses increases from 469 (frequent, low magnitude event) to 758 (infrequent, high magnitude event).

Table 3: Results of the VIE index without measures, depending on the hazard scenarios

\begin{tabular}{|c|c|c|c|c|c|c|c|c|}
\hline \multirow[b]{2}{*}{ Class A } & \multicolumn{2}{|c|}{$\begin{array}{c}\text { Frequent event } \\
\text { (3.60m NGF) }\end{array}$} & \multicolumn{2}{|c|}{$\begin{array}{l}\text { Medium event } \\
(4.20 \mathrm{~m} \text { NGF) }\end{array}$} & \multicolumn{2}{|c|}{$\begin{array}{c}\text { Medium event + SLR } \\
(4.80 \mathrm{~m} \mathrm{NGF})\end{array}$} & \multicolumn{2}{|c|}{$\begin{array}{l}\text { Extreme event } \\
(5.20 \mathrm{~m} \text { NGF) }\end{array}$} \\
\hline & 1,312 & $47 \%$ & 1,034 & $37 \%$ & 890 & $32 \%$ & 690 & $26 \%$ \\
\hline Class B & 304 & $11 \%$ & 329 & $12 \%$ & 313 & $11 \%$ & 267 & $10 \%$ \\
\hline Class C & 732 & $26 \%$ & 885 & $31 \%$ & 908 & $32 \%$ & 911 & $35 \%$ \\
\hline Class D & 469 & $16 \%$ & 569 & $20 \%$ & 706 & $25 \%$ & 758 & $29 \%$ \\
\hline $\begin{array}{c}\text { Total of identified } \\
\text { houses }\end{array}$ & 2,817 & $100 \%$ & 2,817 & $100 \%$ & 2,817 & $100 \%$ & 2,626 & $100 \%$ \\
\hline $\begin{array}{c}\text { Non identified } \\
\text { Total }\end{array}$ & $\begin{array}{l}1,251 \\
4,068\end{array}$ & $\begin{array}{l}31 \% \\
100 \%\end{array}$ & $\begin{array}{l}1,251 \\
4,068\end{array}$ & $\begin{array}{l}31 \% \\
100 \%\end{array}$ & $\begin{array}{l}1,251 \\
4,068\end{array}$ & $\begin{array}{c}31 \% \\
100 \%\end{array}$ & $\begin{array}{l}1,442 \\
4,068\end{array}$ & $\begin{array}{c}35 \% \\
100 \%\end{array}$ \\
\hline
\end{tabular}

\subsection{VIE index considering adaptation strategies}

In the second instance, the VIE index was calculated considering the adaptation strategies presented in Section 2.3. These results allow us to compare the results with and without adaptation measures. For example, Figure 4 shows the result of VIE index for the medium hazard event, without measures (above map) and with architectural adaptation of houses (below map). $60 \%$ of La Guérinière houses are single-storey constructions that lack adaptation. This percentage is reduced to $2 \%$ when the adaptation measure is included. This difference has a significant impact on the VIE index; for instance, the black class is reduced from 25\% (without adaptation) to $4 \%$ (after architectural adaptation), thus representing a significant decrease in the vulnerability of houses and their occupants to flooding. 

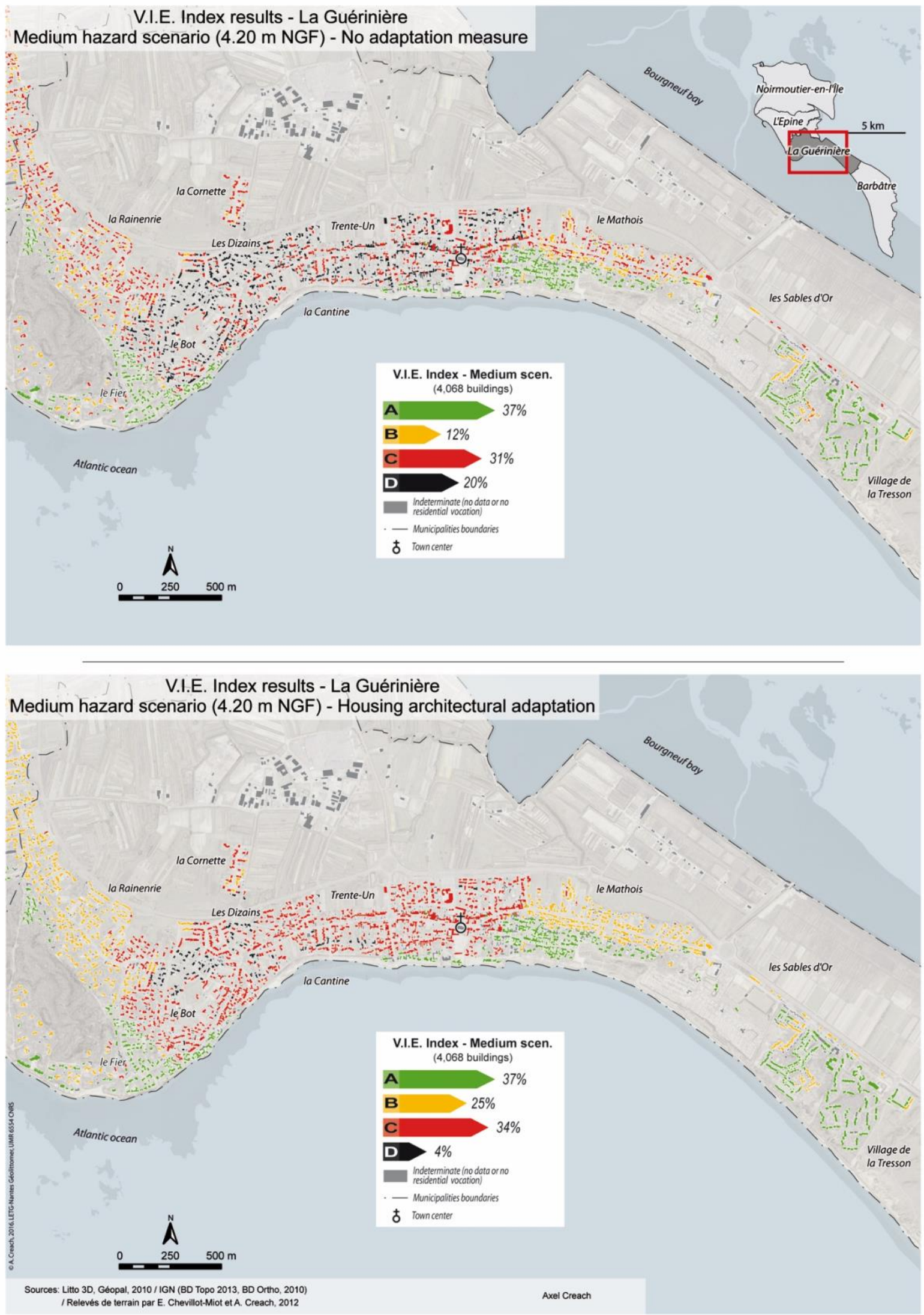

Figure 4: Maps showing the results of the VIE Index on La Guérinière for a medium coastal flood event, without adaptation measures (above) and with housing architectural adaptation (below). 
Tables 4 to 7 summarize the VIE indexes for each of the adaptation strategies. Each adaptation strategy has a different performance depending on the hazard level. In a global manner, retreat is the most efficient measure because all the houses considered as the most dangerous (black class) are demolished. As seen in Table 4, the black class is empty. However, from political, economical and social points of view, it is harder to implement when considering the destruction of $16 \%$ (frequent event) to $29 \%$ (extreme event) of the municipality buildings [54].

The second most efficient measure is that of housing architectural adaptation (Table 5). It reduces the number of dangerous houses from $95 \%$ (for a frequent event) to $42 \%$ (for an extreme event) with respect to the initial situation (Table 3). The protection measure (Table 6) reduces this part from $46 \%$ (frequent event) to $26 \%$ (extreme event). Finally, warning and evacuation measures appear to be less efficient (Table 7), but their efficiency increases with the intensity of the coastal flood hazard. For example, for a frequent event, it reduces the portion of black class houses from $2.3 \%$, whereas this portion reaches $14 \%$ for an extreme event. This inefficiency is because of human behaviour rather than housing architectural adaptation while the efficiency is, here, only measured in terms of the number of "dangerous" houses.

Table 4: Results of the VIE index for retreat measures, depending of the hazard scenarios

\begin{tabular}{|c|c|c|c|c|c|c|c|c|}
\hline & \multicolumn{2}{|c|}{$\begin{array}{c}\text { Frequent event } \\
(3.60 \mathrm{~m} \mathrm{NGF})\end{array}$} & \multicolumn{2}{|c|}{$\begin{array}{l}\text { Medium event } \\
\text { (4.20m NGF) }\end{array}$} & \multicolumn{2}{|c|}{$\begin{array}{c}\text { Medium event + SLR } \\
(4.80 \mathrm{~m} \mathrm{NGF})\end{array}$} & \multicolumn{2}{|c|}{$\begin{array}{l}\text { Extreme event } \\
(5.20 \mathrm{~m} \mathrm{NGF})\end{array}$} \\
\hline Class A & 1,312 & $56 \%$ & 1,034 & $46 \%$ & 890 & $42 \%$ & 690 & $37 \%$ \\
\hline Class B & 304 & $13 \%$ & 329 & $15 \%$ & 313 & $15 \%$ & 267 & $14 \%$ \\
\hline Class C & 732 & $31 \%$ & 885 & $39 \%$ & 908 & $43 \%$ & 911 & $49 \%$ \\
\hline Class D & 0 & $0 \%$ & 0 & $0 \%$ & 0 & $0 \%$ & 0 & $0 \%$ \\
\hline $\begin{array}{c}\text { Total of identified } \\
\text { houses }\end{array}$ & 2,348 & $100 \%$ & 2,248 & $100 \%$ & 2,111 & $100 \%$ & 1,868 & $100 \%$ \\
\hline $\begin{array}{c}\text { Non identified } \\
\text { Total }\end{array}$ & $\begin{array}{l}1,251 \\
3,599\end{array}$ & $\begin{array}{l}35 \% \\
100 \%\end{array}$ & $\begin{array}{l}1,251 \\
3,499\end{array}$ & $\begin{array}{c}36 \% \\
100 \%\end{array}$ & $\begin{array}{l}1,251 \\
3,362\end{array}$ & $\begin{array}{c}37 \% \\
100 \%\end{array}$ & $\begin{array}{l}1,442 \\
3,310\end{array}$ & $\begin{array}{c}44 \% \\
100 \%\end{array}$ \\
\hline
\end{tabular}

Table 5: Results of the VIE index for housing architectural adaptation measures, depending on the hazard scenarios

\begin{tabular}{|c|c|c|c|c|c|c|c|c|}
\hline \multirow[b]{2}{*}{ Class A } & \multicolumn{2}{|c|}{$\begin{array}{l}\text { Frequent event } \\
(3.60 \mathrm{~m} \text { NGF) }\end{array}$} & \multicolumn{2}{|c|}{$\begin{array}{l}\text { Medium event } \\
\text { (4.20m NGF) }\end{array}$} & \multicolumn{2}{|c|}{$\begin{array}{c}\text { Medium event + SLR } \\
(4.80 \mathrm{~m} \text { NGF })\end{array}$} & \multicolumn{2}{|c|}{$\begin{array}{l}\text { Extreme event } \\
\text { (5.20m NGF) }\end{array}$} \\
\hline & 1,312 & $47 \%$ & 1,034 & $36 \%$ & 890 & $32 \%$ & 690 & $26 \%$ \\
\hline Class B & 631 & $22 \%$ & 701 & $25 \%$ & 618 & $22 \%$ & 588 & $22 \%$ \\
\hline Class C & 848 & $30 \%$ & 975 & $35 \%$ & 966 & $34 \%$ & 906 & $35 \%$ \\
\hline Class D & 26 & $1 \%$ & 107 & $4 \%$ & 343 & $12 \%$ & 442 & $17 \%$ \\
\hline $\begin{array}{c}\text { Total of identified } \\
\text { houses }\end{array}$ & 2,817 & $100 \%$ & 2,817 & $100 \%$ & 2,817 & $100 \%$ & 2,626 & $100 \%$ \\
\hline $\begin{array}{l}\text { Non identified } \\
\text { Total }\end{array}$ & $\begin{array}{l}1,251 \\
4,068\end{array}$ & $\begin{array}{l}31 \% \\
100 \%\end{array}$ & $\begin{array}{l}1,251 \\
4,068\end{array}$ & $\begin{array}{l}31 \% \\
100 \%\end{array}$ & $\begin{array}{l}1,251 \\
4,068\end{array}$ & $\begin{array}{l}31 \% \\
100 \%\end{array}$ & $\begin{array}{l}1,442 \\
4,068\end{array}$ & $\begin{array}{c}35 \% \\
100 \%\end{array}$ \\
\hline
\end{tabular}

Table 6: Results of the VIE index for protection measures, depending on the hazard scenarios

\begin{tabular}{|c|c|c|c|c|c|c|c|c|}
\hline \multirow[b]{2}{*}{ Class A } & \multicolumn{2}{|c|}{$\begin{array}{c}\text { Frequent event } \\
(3.60 \mathrm{~m} \mathrm{NGF})\end{array}$} & \multicolumn{2}{|c|}{$\begin{array}{l}\text { Medium event } \\
(4.20 \mathrm{~m} \text { NGF) }\end{array}$} & \multicolumn{2}{|c|}{$\begin{array}{c}\text { Medium event + SLR } \\
\quad(4.80 \mathrm{~m} \mathrm{NGF})\end{array}$} & \multicolumn{2}{|c|}{$\begin{array}{c}\text { Extreme event } \\
(5.20 \mathrm{~m} \mathrm{NGF})\end{array}$} \\
\hline & 1,312 & $47 \%$ & 1,034 & $37 \%$ & 890 & $31 \%$ & 690 & $26 \%$ \\
\hline Class B & 364 & $13 \%$ & 382 & $14 \%$ & 320 & $11 \%$ & 268 & $10 \%$ \\
\hline Class C & 889 & $31 \%$ & 1,015 & $35 \%$ & 1,085 & $39 \%$ & 1,106 & $42 \%$ \\
\hline Class D & 252 & $9 \%$ & 386 & $14 \%$ & 522 & $19 \%$ & 562 & $22 \%$ \\
\hline $\begin{array}{c}\text { Total of identified } \\
\text { houses }\end{array}$ & 2,817 & $100 \%$ & 2,817 & $100 \%$ & 2,817 & $100 \%$ & 2,626 & $100 \%$ \\
\hline $\begin{array}{l}\text { Non identified } \\
\text { Total }\end{array}$ & $\begin{array}{l}1,251 \\
4,068\end{array}$ & $\begin{array}{c}31 \% \\
100 \%\end{array}$ & $\begin{array}{l}1,251 \\
4,068\end{array}$ & $\begin{array}{c}31 \% \\
100 \%\end{array}$ & $\mid \begin{array}{l}1,251 \\
4,068\end{array}$ & $\begin{array}{c}31 \% \\
100 \%\end{array}$ & $\begin{array}{l}1,442 \\
4,068\end{array}$ & $\begin{array}{c}35 \% \\
100 \%\end{array}$ \\
\hline
\end{tabular}


Table 7: Results of the VIE index for warning and evacuation measures, depending on the hazard scenarios

\begin{tabular}{|c|c|c|c|c|c|c|c|c|}
\hline & \multicolumn{2}{|c|}{$\begin{array}{c}\text { Frequent event } \\
(3.60 \mathrm{~m} \mathrm{NGF})\end{array}$} & \multicolumn{2}{|c|}{$\begin{array}{l}\text { Medium event } \\
(4.20 \mathrm{~m} \text { NGF) }\end{array}$} & \multicolumn{2}{|c|}{$\begin{array}{c}\text { Medium event + SLR } \\
\quad(4.80 \mathrm{~m} \mathrm{NGF})\end{array}$} & \multicolumn{2}{|c|}{$\begin{array}{c}\text { Extreme event } \\
\text { (5.20m NGF) }\end{array}$} \\
\hline Class A & 1,312 & $47 \%$ & 1,034 & $37 \%$ & 890 & $32 \%$ & 690 & $26 \%$ \\
\hline Class B & 304 & $11 \%$ & 362 & $13 \%$ & 378 & $13 \%$ & 314 & $12 \%$ \\
\hline Class C & 743 & $26 \%$ & 914 & $32 \%$ & 931 & $33 \%$ & 970 & $37 \%$ \\
\hline Class D & 458 & $16 \%$ & 507 & $18 \%$ & 618 & $22 \%$ & 652 & $25 \%$ \\
\hline $\begin{array}{c}\text { Total of identified } \\
\text { houses }\end{array}$ & 2,817 & $100 \%$ & 2,817 & $100 \%$ & 2,817 & $100 \%$ & 2,626 & $100 \%$ \\
\hline $\begin{array}{c}\text { Non identified } \\
\text { Total }\end{array}$ & $\begin{array}{l}1,251 \\
4,068\end{array}$ & $\begin{array}{c}31 \% \\
100 \%\end{array}$ & $\begin{array}{l}1,251 \\
4,068\end{array}$ & $\begin{array}{c}31 \% \\
100 \%\end{array}$ & $\begin{array}{l}1,251 \\
4,068\end{array}$ & $\begin{array}{c}31 \% \\
100 \%\end{array}$ & $\begin{array}{l}1,442 \\
4,068\end{array}$ & $\begin{array}{c}35 \% \\
100 \%\end{array}$ \\
\hline
\end{tabular}

\subsection{Costs of adaptation scenarios}

Underpinning the theoretical efficiency, each adaptation strategy has a cost which is estimated according to the values described in Section 2.3. This section provides the overall cost for the implementation of the strategies. The detailed costs per strategy and for the different hazard scenarios, are detailed in Appendix A. These costs are given for investment and maintenance over total lifetimes of 20, 50 and 100 years, considering the discount rates defined in Section 2.4.

Figure 5 summarizes the costs for the considered adaptation strategies and hazard scenarios. The evolution of cost is also given for the two strategies that are concerned with maintenance (protection, warning and evacuation) as a function of the expected lifetime. There are major differences in the costs of each of the four strategies. The cost and efficiency trends follow the same pattern: the most efficient strategies are the most expensive. Retreat is the most efficient and expensive adaptation strategy. Its cost varies between $€ 138$ billion ( 469 houses in the black class to be demolished), and $€ 228$ billion (758 houses in the black class to be demolished) for frequent and extreme coastal flood events, respectively. These costs are around ten times greater than the cost of housing architectural adaptation that ranges from $€ 17$ billion (adaptation of 860 single-story houses) to $€ 22.5$ billion (adaptation of 1,167 singlestory houses) for frequent and extreme coastal flood events, respectively.

Figure 5 also indicates that the cost of protection is not influenced by the coastal flood hazard level. Rather it is controlled by an arbitrary renovation of dike elevation ( $+5 \mathrm{~m}-\mathrm{NGF})$ imposed for all hazard scenarios in keeping with work done previously by Noirmoutier Council.

The initial cost of protection is $€ 3.8$ billion. Depending on the envisaged maintenance and lifetime of the coastal defences, the total cost could reach $€ 5.9$ billion in 100 years. Finally, the less efficient strategy, warning and evacuation, appears to be around 100 times cheaper than the retreat strategy. The initial investment costs vary from $€ 1.6$ billion to $€ 2.4$ billion for frequent to extreme events, respectively. As mentioned in Section 0, to be efficient, this measure needs to maintain population risk awareness with updates every 5 years (documents and evacuation training). In consequence, for a lifetime of 100 years, the cost increases from $€ 3.9$ billion to $€ 4.9$ billion for frequent and extreme events, respectively.

These first results estimate the level of efficiency and costs for each adaptation strategy. A measure is proposed in the following section to relate both indicators. 


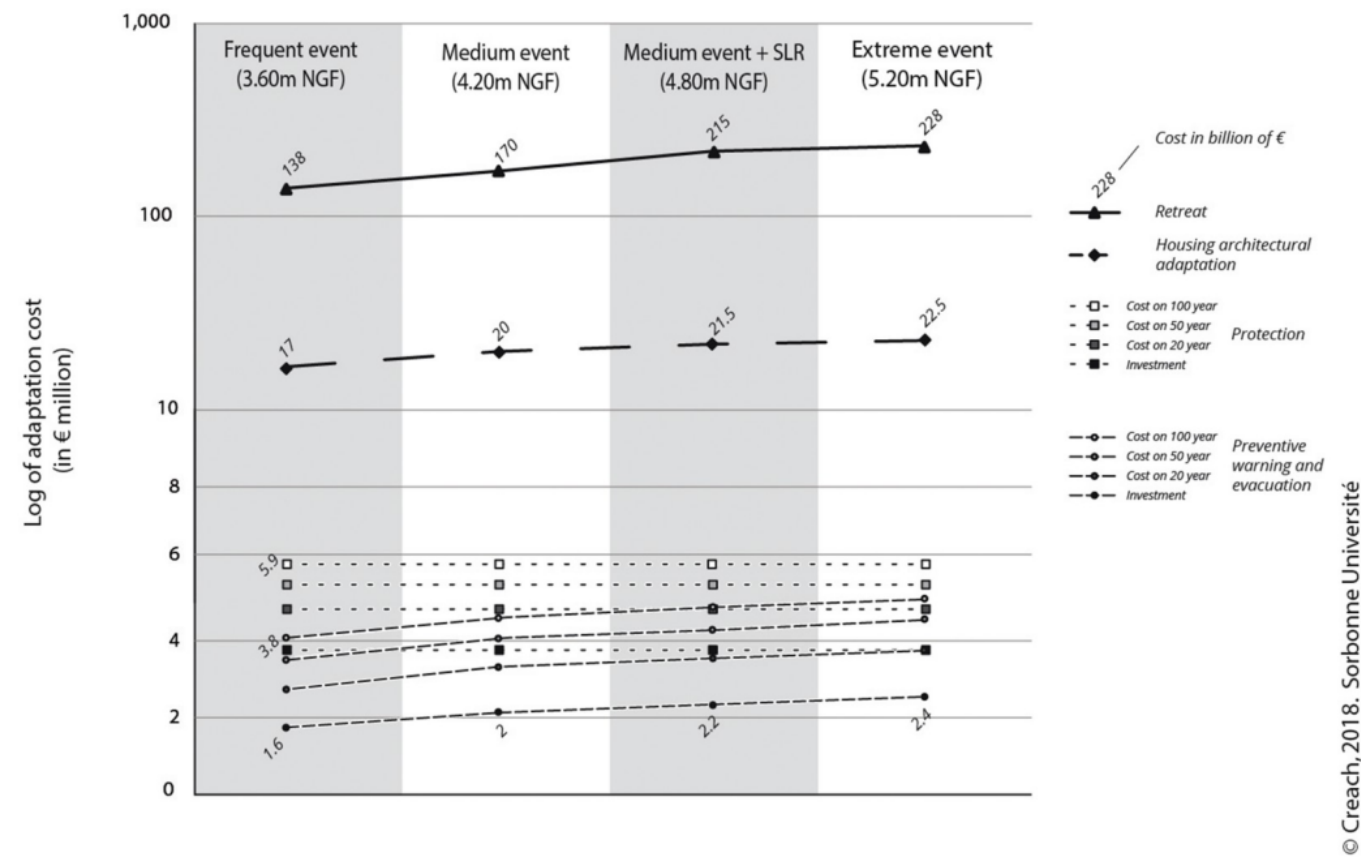

Figure 5: Summary of the costs of various adaptation measures, depending on the hazard scenario

\section{Discussion}

\subsection{Assessment of the cost/efficiency of adaptation strategies}

Cost and efficiency results separately do not provide sufficient information for policy makers. The European Commission [50] recommends performing an economic analysis in flood management projects to ensure transparency [55] and to provide firm choices in the context of SLR [56]. Different methods are used for economic analysis [57]: (i) cost-benefit analyses, (ii) cost-effectiveness analyses, and (iii) multicriteria analyses, etc. In this study, we propose to link (i) the adaptation cost with (ii) the reduction of risk related to the implementation of an adaptation strategy, $\Delta$ risk. $\Delta$ risk (as a percentage) is estimated as a function of the number houses in the black class with and without the implementation of the adaptation strategy by using the following equation:

$$
\Delta \text { risk }=\frac{n b_{\text {with adap }}-n b_{\text {without } a d a p}}{n b_{\text {without } \text { adap }}} \times 100
$$

where $n b_{\text {with adap }}$ and $n b_{\text {without adap }}$ are respectively the number of houses in the black class with and without considering the adaptation strategy. $n b_{\text {with adap }}$ and $n b_{\text {without adap }}$ are estimated from the results presented in Section 3.

Figure 6 shows the adaptation costs and $\Delta$ risk of the considered adaptation strategies. The analysis also indicates that the reduction of risk is most important for the more expensive adaptation strategies. Strategies when ranked from the most efficient and expensive to the less efficient and expensive are as follows: (i) retreat; (ii) housing architectural adaptation; and (iii) protection, warning and evacuation. These results indicate that the choice of the adaptation strategy revolves around the goal which is either to maximize efficiency or minimize costs. Nevertheless, these results (and therefore the ranking) could have some limitations, especially for efficiency assessments for which there are many uncertainties.

The main uncertainty is related to human behaviour. Indeed, to assess the efficiency of strategies to protect human life we used an index based on the vulnerability of houses for people. However, human 
behaviour can increase or lower vulnerability. During Storm Xynthia, there were five deaths in houses where people had the possibility of escaping to a higher floor. As a consequence it can be concluded that architectural adaptation is not sufficient to prevent death in the case of flooding because human behaviour is a key factor $[3,14,34]$.

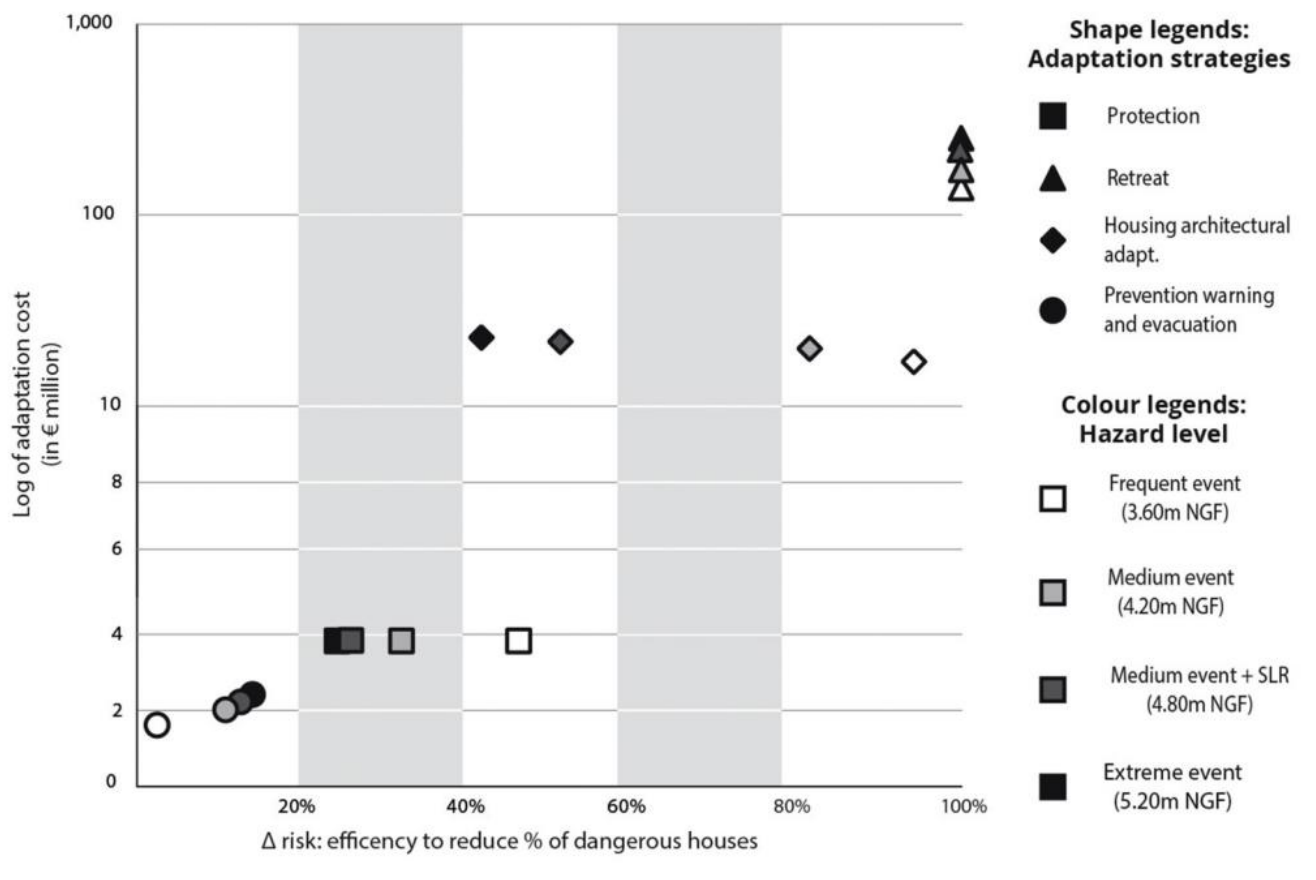

Figure 6: Summary of the cost/efficiency evaluation

Thus, prevention, warning and evacuation can be viewed as an important strategy to reduce loss of life. The fact that it appears to be the less efficient strategy in the present work is because efficiency is measured as a reduction of building's vulnerability for people. To be more realistic, efficiency should be measured as a number of lives potentially saved with adaptation strategies. Several existing methods could be used [58]. By measuring efficiency in terms of the number of lives saved, prevention warning and evacuation would probably appear far more efficient and at an affordable cost.

Uncertainties regarding costs also need to be considered. First, he cost of protection had been estimated for reinforcement and increasing the elevation of flood defences to $5 \mathrm{~m} \mathrm{NGF}$, which is below the projected sea level for an extreme event $(5.20 \mathrm{~m} \mathrm{NGF})$. It would be useful to estimate the costs associated with increasing the elevation of flood defences to over $5 \mathrm{~m} \mathrm{NGF}$ which would undoubtedly increase the total cost of the strategy. Sea level rise may necessitate further upgrades in coastal defences that result in exponential costs [26]. Second, the cost of retreat is an average cost of different websites based on real-estate estimation. The sources of their dataset are not clearly explained in the websites which introduces uncertainties regarding future costs.

Other limitations of this study include the efficiency of the protection strategy in relation to an extreme event. For a sea-water level of $5.20 \mathrm{~m}$ NGF, $5 \mathrm{~m}$ high flood defences are likely to be overtopped, and consequently, the strategy is not sufficient to cope with high magnitude flooding events.

Finally, this study addresses the cost/efficiency of adaptation strategies separately. However, the best way to reduce the vulnerability of houses for people is to combine prevention of inhabitants with different levels of adaptation and protection. Combining these measures could contribute to the increased awareness of inhabitants in flood-prone coastal areas. The utilisation of structural strategies to reduce the vulnerability of houses and the occupants could help to optimise costs [10]. 


\subsection{The VIE index: limits of datasets and method}

The VIE index is a key issue for this study because it estimates the vulnerability of houses and their occupants to flooding as well as considering the efficiency of the different adaptation strategies. Nevertheless, some limits need to be highlighted regarding both the methods and datasets used.

First, an inherent limitation of the dataset used is the architectural type of house, which is used for the calculation of the third criterion of the index. It was obtained by [8]. This study performed field observations in order to determine the type of building. Nevertheless, this work was only carried out for houses exposed to flood for the medium + SLR scenario (4.80 m NGF) and more frequent scenarios. Houses outside the flood zone in this scenario are expected not to be vulnerable according to the VIE index and so no field observations were made for it. For the present study, the vulnerability of houses was analysed for people in relation to an extreme coastal flooding event (5.20 m NGF). Logically, more houses are included than for the previously mentioned scenario; however, due to the data available, no architectural type is known for these houses which introduce errors when recalculating the VIE index for these buildings. Thus, there are 191 houses (7\% of buildings) for which the VIE Index is calculated based on the other scenarios. In consequence, for the extreme scenario, the non-identified class is more important than for the other scenarios.

Second, Creach et al. [5] presented limits of the VIE index method and proposed different ways to improve it. The main limit is the use of a static flood method which increases the potential water level, particularly in extensively flooded areas like marshes [52]. To be more realistic, a twodimensional hydraulic model coupled with a probabilistic model of the failure of the flood defences could be utilised [59]. However, the static method allows every building in a potentially flooded area to be ranked equally and to focus more on the vulnerability than the hazard. It offers the possibility of modelling the worst case scenario, which is the focus of emergency planning efforts [24].

Finally, two additional parameters overestimate the potential water level inside the buildings and could increase the result of the first parameter of the VIE index. This level is estimated on the basis of the flood level and the ground level of the house. The ground level of the house is taken from the ground level derived from LiDAR datasets. [60] identify several uncertainties for LiDAR datasets, particularly in marshes for which the accuracy could be lower owing to the presence of water. Urbanized areas could also be sources of uncertainty. For example, the Litto-3D program [53] gives an accuracy of $+/-20 \mathrm{~cm}$ in elevation for the Digital Elevation Model in the worst cases. Moreover, we used the ground level as the reference for the ground floor of houses. Nevertheless, there is in some cases a difference of 20-60 $\mathrm{cm}$ between the ground level and the ground floor. This difference is automatically added to the potential water level which is probably overestimated.

\section{Conclusions}

In this study we have identified four strategies to reduce the vulnerability of houses for people in the context of SLR: (i) protection with the reinforcement and increased height of existing flood defences, (ii) retreat of buildings most at risk of flooding, (iii) housing architectural adaptation, and (iv) preventive warning and evacuation. These four strategies were applied on a virtual basis to La Guérinière town which is particularly susceptible to coastal flooding. This was carried out to compare the costs and the efficiency of their implementation for four coastal flood events: frequent, medium, medium + SLR and extreme. Assessments of probable costs are rooted in other estimates provided in the literature. Efficiency was assessed using the VIE Index method [5] which evaluates the vulnerability of houses for people. It was observed that the costliest strategies are also the most efficient. Ranked from the most to the least expensive and efficient, they are: (i) retreat (more than $€ 138$ billion), (ii) housing architectural adaptation (more than $€ 17$ billion), (iii) protection (more than $€ 3.8$ billion), and (iv) prevention (more than $€ 1,6$ billion). Costs increase and efficiency decreases for greater coastal flood intensity.

Despite its cost, the retreat strategy is necessary for the most exposed houses. Housing architectural adaptation is a less expensive strategy which can be adopted for the least exposed houses. 
Protection and preventive warning and evacuation are less efficient. However, it is important to highlight that the way to measure efficiency of the strategies has some limitations. Although we measure it in terms of the reduction in the proportion of dangerous houses (black class of the VIE Index), the preventive warning and evacuation strategy is more focused on the improvement of human behaviour than on the reduction of the level of vulnerability of houses for people. The best way would be to assess the efficiency in terms of the number of lives saved when each strategy is employed. This could be done using methods of estimating flood fatalities and introducing a parameter of vulnerability of houses for people which can increase or decrease the risk of death. This may be a viable way to assess the costefficiency of adaptation strategies to coastal flooding within the context of SLR.

\section{Acknowledgements}

The authors are grateful to Martin Paillart from the Communauté de Communes de l'île de Noirmoutier for material support on the island, and all the $\mathrm{PhD}$ students who helped with data collection in the field. In particular, we thank Elie Chevillot-Miot, and the Geopal program for all their help with dataset collection. We also thank Oumar Sylla, Vincent Dollet, Romain Festuot, Laura Guillaume, and TDEM construction company for providing useful information to estimate the costs of adaptation strategies. Thanks to Jan Bloemendal for the careful rereading of the manuscript.

This work was supported by COSELMAR research program, funded by the Regional Council of Pays de la Loire.

\section{References}

[1] X. Bertin, N. Bruneau, J.-F. Breilh, A.B. Fortunato, M. Karpytchev, Importance of wave age and resonance in storm surges: The case Xynthia, Bay of Biscay, Ocean Modelling. 42 (2012) 16-30. doi:10.1016/j.ocemod.2011.11.001.

[2] F. Verger, Digues et polders littoraux: réflexions après la tempête Xynthia, Physio-Géo. Géographie, physique, et environnement. 5 (2011) 95-105. doi:10.4000/physio-geo.1740.

[3] F. Vinet, L. Boissier, S. Defossez, La mortalité comme expression de la vulnérabilité humaine face aux catastrophes naturelles: deux inondations récentes en France (Xynthia, Var, 2010), VertigO-La Revue Électronique En Sciences de l'environnement. 11 (2011) 28. doi:10.4000/vertigo.11074.

[4] F. Leone, F. Lavigne, R. Paris, J.-C. Denain, F. Vinet, A spatial analysis of the December 26th, 2004 tsunami-induced damages: Lessons learned for a better risk assessment integrating buildings vulnerability, Applied Geography. 31 (2011) 363-375. doi:10.1016/j.apgeog.2010.07.009.

[5] A. Creach, S. Pardo, P. Guillotreau, D. Mercier, The use of a micro-scale index to identify potential death risk areas due to coastal flood surges: lessons from Storm Xynthia on the French Atlantic coast, Nat Hazards. 77 (2015) 1679-1710. doi:10.1007/s11069-015-1669-y.

[6] D. Mercier, C. Chadenas, La tempête Xynthia et la cartographie des « zones noires » sur le littoral français : analyse critique à partir de l'exemple de La Faute-sur-Mer (Vendée), Norois. $\mathrm{n}^{\circ} 222$ (2012) 45-60.

[7] Cour des Comptes, Les enseignements des inondations de 2010 sur le littoral atlantique (Xynthia) et dans le Var, Cours des Comptes, 2012.

[8] A. Creach, E. Chevillot-Miot, D. Mercier, L. Pourinet, Vulnerability to coastal flood hazard of residential buildings on Noirmoutier Island (France), Journal of Maps. 0 (2015) 1-11. doi:10.1080/17445647.2015.1027041.

[9] P. Fattal, M. Robin, M. Paillart, M. Maanan, D. Mercier, C. Lamberts, S. Costa, Effets des tempêtes sur une plage aménagée et à forte protection côtière: la plage des Éloux (côte de Noirmoutier, Vendée, France), Norois. 215 (2010) 101-114. 
[10] A. Creach, Cartographie et analyse économique de la vulnérabilité du littoral atlantique français face au risque de submersion marine (2 volumes), Université de Nantes, 2015. https://tel.archivesouvertes.fr/tel-01275600.

[11] INSEE, Recensement général de la population 2011 (Publié le 26 juin 2014), Insee, 2014. http://www.insee.fr/fr/bases-de-donnees/default.asp?page=recensements.htm.

[12] E. Devaux, G. Désiré, C. Boura, J. Lowenbruck, N. Bérenger, N. Rouxel, N. Romain, La tempête Xynthia du 28 février 2010 - Retour d'expérience en Loire-Atlantique et Vendée - Volet hydaulique et ouvrages de protection, CETE-Ouest / DREAL Pays-de-la-Loire / DDTM LoireAtlantique / DDTM Vendée, 2012.

[13] E. Garnier, N. Henry, J. Desarthe, Visions croisées de l'historien et du courtier en réassurance sur les submersions : recrudescence de l'aléa ou vulnérabilisation croissante ?, in: Gestion des risques naturels - Leçons de la tempête Xynthia, Quae, Versailles, 2012: p. 23.

[14] S.N. Jonkman, I. Kelman, An analysis of the causes and circumstances of flood disaster deaths, Disasters. 29 (2005) 75-97.

[15] L. Boissier, La mortalité liée aux crues torentielles dans le sud de la France : une approche de la vulnérabilité humaine face au risque d'inondation, Université Paul Valéry-Montpellier III, 2013.

[16] S.N. Jonkman, B. Maaskant, E. Boyd, M.L. Levitan, Loss of life caused by the flooding of New Orleans after Hurricane Katrina: analysis of the relationship between flood characteristics and mortality, Risk Anal. 29 (2009) 676-698. doi:10.1111/j.1539-6924.2008.01190.x.

[17] J. Klugman, F. Rodríguez, H.-J. Choi, The HDI 2010: new controversies, old critiques, J Econ Inequal. 9 (2011) 249-288. doi:10.1007/s10888-011-9178-z.

[18] R.P. Paskoff, Potential Implications of Sea-Level Rise for France, Journal of Coastal Research. 20 (2004) 424-434.

[19] R.J.T. Klein, R.J. Nicholls, S. Ragoonaden, M. Capobianco, J. Aston, E.N. Buckley, Technological Options for Adaptation to Climate Change in Coastal Zones, Journal of Coastal Research. 17 (2001) 531-543.

[20] R. Nicholls, Planning for the Impacts of Sea Level Rise, Oceanography. 24 (2011) 144-157. doi:10.5670/oceanog.2011.34.

[21] S. Priest, T. Wilson, S. Tapsell, E. Penning-Rowsell, C. Viavattene, A. Fernandez-Bilbao, Building a model to estimate Risk to Life for European flood events, Middlesex University, 2007.

[22] D. Lumbroso, F. Vinet, A comparison of the causes, effects and aftermaths of the coastal flooding of England in 1953 and France in 2010, Natural Hazards and Earth System Science. 11 (2011) 2321-2333. doi:10.5194/nhess-11-2321-2011.

[23] B. Kolen, R. Slomp, S. n. Jonkman, The impacts of storm Xynthia February 27-28, 2010 in France: lessons for flood risk management, J. Flood Risk Manage. 6 (2013) 261-278. doi:10.1111/jfr3.12011.

[24] D. Lumbroso, M. Davison, Use of an agent-based model and Monte Carlo analysis to estimate the effectiveness of emergency management interventions to reduce loss of life during extreme floods, J. Flood Risk Manage. (2016) 16. doi:10.1111/jfr3.12230.

[25] MEDDE, Stratégie nationale de gestion intégrée du trait de côte - Vers la relocalisation des activités et des biens, Ministère de l'Écologie, du Développement durable et de l'Énergie, 2012.

[26] S.N. Jonkman, M.M. Hillen, R.J. Nicholls, W. Kanning, M. van Ledden, Costs of Adapting Coastal Defences to Sea-Level Rise- New Estimates and Their Implications, Journal of Coastal Research. 29 (2013) 1212-1226. doi:10.2112/JCOASTRES-D-12-00230.1.

[27] F. Vinet, Le risque inondation. Diagnostic et gestion., Tec \& Doc Lavoisier, Paris, 2010. 
[28] V. Dollet, O. Sylla, Techniques de renforcement et coûts d'adaptation des digues face à des nouveaux risques en lien avec le changement climatique - Application au cas de l'Ile de Noirmoutier, Université de Nantes - M2 GC CRB, Saint-Nazaire, 2015.

[29] L. Goeldner-Gianella, F. Bertrand, A. Oiry, D. Grancher, Depolderisation policy against coastal flooding and social acceptability on the French Atlantic coast: The case of the Arcachon Bay, Ocean and Coastal Management. 116 (2015) 98-107. doi:10.1016/j.ocecoaman.2015.07.001.

[30] MEDDE, METL, Référentiel de travaux de prévention du risque d'inondation dans l'habitat existant, 2012.

[31] F. Vinet, D. Lumbroso, S. Defossez, L. Boissier, A comparative analysis of the loss of life during two recent floods in France: the sea surge caused by the storm Xynthia and the flash flood in Var, Nat Hazards. 61 (2012) 1179-1201. doi:10.1007/s11069-011-9975-5.

[32] R. Festuot, L. Guillaume, R\&D : Etude technico économique sur la réduction de la vulnérabilité des constructions de plain pied soumise à des risques de submersions, Université de Nantes - M2 GC CRB, Saint-Nazaire, 2015.

[33] C. Chadenas, A. Creach, D. Mercier, The impact of storm Xynthia in 2010 on coastal flood prevention policy in France, J Coast Conserv. 18 (2013) 529-538. doi:10.1007/s11852-013-02993.

[34] D.J. Parker, S.J. Priest, S.M. Tapsell, Understanding and enhancing the public's behavioural response to flood warning information, Met. Apps. 16 (2009) 103-114. doi:10.1002/met.119.

[35] CdA La Rochelle, Programme d'Action de Prévention des Inondations «Agglomération Rochelaise », Communauté d'agglomération de La Rochelle, 2013.

[36] P. Dasgupta, Discounting Climate Change, Journal of Risk and Uncertainty. 37 (2008) 141-169.

[37] D. Lebègue, L. Baumstark, P. Hirtzman, Révision du taux d'actualisation des investissements publics, Commissariat Général du Plan, 2005. http://www.reesfrance.com/IMG/pdf/2005_RAPPORT_LEBEGUE_-tauxactualisation.pdf.

[38] C. Gollier, Pricing the Planet's Future: The Economics of Discounting in an Uncertain World, Princeton University Press, New Jersey., 2012.

[39] E. Quinet, L'évaluation socioéconomique des investissements publics, Commissariat Général à la Strategie et à la Prospective (In French), Paris, France, 2013.

[40] M. Harrison, Valuing the Future: the social discount rate in cost-benefit analysis, Visiting Researcher Paper, Productivity Commission, Canberra., 2010.

[41] IA, Outline of Infrastructure Australia's Prioritisation Methodology, Infrastructure Australia, Australian Government, Canberra, 24 September 2008., 2008.

[42] A.E. Boardman, D.H. Greenberg, A.R. Vining, D.L. Weimer, Cost-Benefit Analysis: Concepts and Practice, Pearson, Boston, 2011.

[43] HM Treasury, The Green Book: Appraisal and Evaluation in Central Government, 2003.

[44] W.K. Viscusi, Rational Discounting for Regulatory Analysis, The University of Chicago Law Review. 74 (2007) 209-246.

[45] OBPR, Best Practice Regulation Handbook, Camberra, 2010.

[46] N. Stern, The Economics of Climate Change: The Stern Review, Cabinet Office - HM Treasury, London., 2006.

[47] R. Garnaut, The Garnaut Climate Change Review: Final Report, Commonwealth of Australia, Cambridge University Press, U.K., 2008.

[48] W.D. Nordhaus, A Review of the Stern Review on the Economics of Climate Change, Journal of Economic Literature. XLV (2007) 686-702. 
[49] BTRE, Report 110: Risk in cost-benefit analysis, Bureau of Transport and Regional Economics, Australian Government, Canberra., 2005.

[50] European Commission/Commission Européenne, Directive 2007/60/CE du Parlement Européen et du Conseil du 23 octobre 2007 relative à l'évaluation et à la gestion des risques d'inondation, 2007.

[51] DREAL Pays de la Loire, Rapport de présentation de la cartographie du risque de submersion marine sur le secteur Noirmoutier - Saint Jean de Monts (Directive inondations Bassins LoireBretagne), DREAL Pays de la Loire, 2014.

[52] J.-F. Breilh, E. Chaumillon, X. Bertin, M. Gravelle, Assessment of static flood modeling techniques: application to contrasting marshes flooded during Xynthia (western France), Nat. Hazards Earth Syst. Sci. 13 (2013) 1595-1612. doi:10.5194/nhess-13-1595-2013.

[53] IGN, SHOM, Litto3D® - v 1.0 - Spécifications techniques, IGN/SHOM, 2012.

[54] D. King, D. Bird, K. Haynes, H. Boon, A. Cottrell, J. Millar, T. Okada, P. Box, D. Keogh, M. Thomas, Voluntary relocation as an adaptation strategy to extreme weather events, International Journal of Disaster Risk Reduction. 8 (2014) 83-90. doi:10.1016/j.ijdrr.2014.02.006.

[55] OCDE, L'évaluation environnementale stratégique, Editions OCDE, Paris, 2006. http://www.oecd-ilibrary.org/content/book/9789264026803-fr (accessed August 19, 2015).

[56] GIEC, Climate Change 2014: Impacts, Adaptation and Vulnerability, GIEC/IPCC, 2014.

[57] V. Markantonis, V. Meyer, R. Schwarze, Review Article "Valuating the intangible effects of natural hazards - review and analysis of the costing methods," Nat. Hazards Earth Syst. Sci. 12 (2012) 1633-1640. doi:10.5194/nhess-12-1633-2012.

[58] M. Di Mauro, K.M.D. Bruijn, M. Meloni, Quantitative methods for estimating flood fatalities: towards the introduction of loss-of-life estimation in the assessment of flood risk, Nat Hazards. 63 (2012) 1083-1113. doi:10.1007/s11069-012-0207-4.

[59] M. Di Mauro, D.M. Lumbroso, Hydrodynamic and loss of life modelling for the 1953 Canvey Island flood, in: Keble College, Oxford, UK, 2008: pp. 1117-11126. http://eprints.hrwallingford.co.uk/230/ (accessed January 16, 2015).

[60] H.M. Cooper, C.H. Fletcher, Q. Chen, M.M. Barbee, Sea-level rise vulnerability mapping for adaptation decisions using LiDAR DEMs, Progress in Physical Geography. (2013) 1-22. doi:10.1177/0309133313496835.

\section{Appendix A: Costs of adaptation strategies}

Table 8 : Cost of the measure of protection

$\begin{array}{lccc} & \text { Dikes } & \text { Sea-wall } & \text { Total } \\ \begin{array}{c}\text { m/l to reinforce } \\ \text { and rise }\end{array} & 4,156 & 2,336 & 6,492 \\ \begin{array}{c}\text { Yearly cost for } \\ \text { maintenance }\end{array} & 41,277 € & 33,903 € & 75,179 € \\ \begin{array}{c}\text { Investment } \\ \text { Cost on 20 years }\end{array} & 2,063,828 € & 1,695,142 € & 3,758,970 € \\ \text { Cost on 50 years } & & & 4,780,682 € \\ \text { Cost on 100 years } & & & 5,437,988 € \\ \end{array}$


Table 9: Cost of the measure of retreat

\begin{tabular}{|c|c|c|c|c|}
\hline & $\begin{array}{l}\text { Frequent event } \\
(3.60 \mathrm{~m} \mathrm{NGF})\end{array}$ & $\begin{array}{l}\text { Medium event } \\
(4.20 \mathrm{~m} \mathrm{NGF})\end{array}$ & $\begin{array}{l}\text { Medium event + SLR } \\
\quad(4.80 \mathrm{~m} \mathrm{NGF})\end{array}$ & $\begin{array}{l}\text { Extreme event } \\
(5.20 \mathrm{~m} \mathrm{NGF})\end{array}$ \\
\hline $\begin{array}{l}\mathrm{Nb} \text { of houses } \\
\text { to be retreated }\end{array}$ & 469 & 569 & 706 & 758 \\
\hline $\begin{array}{c}\text { Total surface }\left(\mathrm{m}^{2}\right) \\
\text { Mean surface/house }\left(\mathrm{m}^{2}\right)\end{array}$ & $\begin{array}{c}46595 \\
99\end{array}$ & $\begin{array}{c}57,599 \\
101\end{array}$ & $\begin{array}{l}73,158 \\
104\end{array}$ & $\begin{array}{l}77470 \\
102\end{array}$ \\
\hline Cost of the $\mathrm{m}^{2}$ & \multicolumn{4}{|c|}{$2,752 €$} \\
\hline Cost of purchase & $128244870 €$ & $158,530,665 €$ & $201,355,956 €$ & $213224001 €$ \\
\hline Mean cost/house & $273443 €$ & $278,613 €$ & $285,207 €$ & $281298 €$ \\
\hline Cost for demolition & \multicolumn{4}{|c|}{$20,000 €$} \\
\hline Total cost for demolition & $9380000 €$ & $11,380,000 €$ & $14,120,000 €$ & $15160000 €$ \\
\hline Total cost of the measure & $137624870 €$ & $169,910,665 €$ & $215,475,956 €$ & $228384001 €$ \\
\hline
\end{tabular}

Table 10: Cost of the measure of housing architectural adaptation

\begin{tabular}{|c|c|c|c|c|}
\hline & $\begin{array}{c}\text { Frequent event } \\
(3.60 \mathrm{~m} \mathrm{NGF})\end{array}$ & $\begin{array}{l}\text { Medium event } \\
(4.20 \mathrm{~m} \text { NGF) }\end{array}$ & $\begin{array}{c}\text { Medium event + SLR } \\
(4.80 \mathrm{~m} \mathrm{NGF})\end{array}$ & $\begin{array}{l}\text { Extreme event } \\
(5.20 \mathrm{~m} \mathrm{NGF})\end{array}$ \\
\hline $\begin{array}{l}\mathrm{Nb} \text { of houses } \\
\text { to transform }\end{array}$ & 860 & 1,024 & 1,120 & 1,167 \\
\hline $\begin{array}{l}\text { Cost for } \\
\text { a shelter }\end{array}$ & \multicolumn{4}{|c|}{$19,265 €$} \\
\hline Total cost & $16,567,900 €$ & $19,727,360 €$ & $21,576,800 €$ & $22,482,255 €$ \\
\hline
\end{tabular}

Table 11: Cost of the measure of prevention and evacuation

\begin{tabular}{|c|c|c|c|c|}
\hline Evacuation equipement & $\begin{array}{l}\text { Frequent event } \\
(3.60 \mathrm{~m} \mathrm{NGF})\end{array}$ & $\begin{array}{l}\text { Medium event } \\
(4.20 \mathrm{~m} \mathrm{NGF})\end{array}$ & $\begin{array}{l}\text { Medium event }+S L R \\
(4.80 \mathrm{~m} \mathrm{NGF})\end{array}$ & $\begin{array}{l}\text { Extreme event } \\
\text { (5.20m NGF) }\end{array}$ \\
\hline $\mathrm{Nb}$ of shelter plateform & 12 & 17 & 19 & 21 \\
\hline Investment & $960,000 €$ & $1,360,000 €$ & $1,520,000 €$ & $1,680,000 €$ \\
\hline Yaerly cost for maintenance & $9,600 €$ & $13,600 €$ & $15,200 €$ & $16,800 €$ \\
\hline \multicolumn{5}{|l|}{ Prevention } \\
\hline $\begin{array}{l}\text { Regulatory documents } \\
\text { and evacuation training }\end{array}$ & \multicolumn{4}{|c|}{$357,000 €$} \\
\hline Yearly cost for upgrade & \multicolumn{4}{|c|}{$71,450 €$} \\
\hline \multicolumn{5}{|l|}{ Stand-by emergency kit } \\
\hline Unit cost & \multicolumn{4}{|c|}{$250 €$} \\
\hline $\begin{array}{c}\mathrm{Nb} \text { of houses concerned } \\
\text { Total cost }\end{array}$ & $\begin{array}{c}1,201 \\
300,250 €\end{array}$ & $\begin{array}{c}1,435 \\
358,750 €\end{array}$ & $\begin{array}{c}1,571 \\
392,750 €\end{array}$ & $\begin{array}{c}1,669 \\
417,250 €\end{array}$ \\
\hline \multicolumn{5}{|l|}{ Total cost of the measure } \\
\hline Total cost & $1,577,250 €$ & $2,035,750 €$ & $2,229,750 €$ & $2,414,250 €$ \\
\hline Yearly cost & $81,050 €$ & $85,050 €$ & $86,650 €$ & $88,250 €$ \\
\hline Cost on 20 years & $2,678,746 €$ & $3,191,607 €$ & $3,407,352 €$ & $3,613,596 €$ \\
\hline Cost on 50 years & $3,387,379 €$ & $3,935,213 €$ & $4,164,947 €$ & $4,385,180 €$ \\
\hline Cost on 100 years & $3,915,831 €$ & $4,489,745 €$ & $4,729,911 €$ & $4,960,576 €$ \\
\hline
\end{tabular}

